\title{
Voltage-dependent Calcium Currents in Purkinje Cells from Rat Cerebellar Vermis
}

\author{
Laura J. Regan \\ Department of Neurobiology, Harvard Medical School, Boston, Massachusetts 02115
}

\begin{abstract}
Whole-cell patch clamp recording was used to characterize calcium currents in Purkinje cells dissociated from the cerebellar vermis of 1-3-week postnatal rats. A subset of Purkinje cells had a low-threshold, transient current similar to the T-type current in peripheral neurons. All Purkinje cells had a high-threshold, slowly inactivating current. Only a small component of the high-threshold current was sensitive to dihydropyridine (DHP) antagonists or to the dihydropyridine agonist BAY K8644. $\omega$-Conotoxin had very little effect on the high-threshold current. The results suggest that these Purkinje cells have at least three types of calcium channels: T-type channels (present in only a fraction of cells), DHP. sensitive L-type channels (contributing a small fraction of the high-threshold current), and a predominant type of highthreshold channel that is pharmacologically distinct from L-type and $\mathrm{N}$-type channels characterized in peripheral neurons.
\end{abstract}

Most electrically excitable cells have multiple types of calcium current that differ in their voltage dependence and pharmacology (for a recent review, see Bean, 1989). In the vertebrate nervous system, voltage-dependent calcium currents have been best characterized in peripheral neurons. Distinct low- and highthreshold components of calcium current have been resolved in sensory neurons (Carbone and Lux, 1984a,b; Bossu et al., 1985; Fedulova et al., 1985; Ikeda et al., 1986). The low-threshold ("T") component, found in a subset of dorsal root ganglion (DRG) neurons, inactivates rapidly during a sustained depolarization. The high-threshold calcium current in DRG cells, originally described as a single long-lasting current (Kostyuk et al., 1981), has been resolved into two components (Nowycky et al., 1985b; Fox et al., 1987a,b; Kasai et al., 1987; Kostyuk et al., 1988). Compared to the previously characterized current (commonly referred to as " $L$ " current), the second type of current ("N" current) was found to inactivate over a broader range of holding potentials, and at a faster rate during a sustained depolarization. However, subsequent studies have demonstrated that rapid inactivation is not always a defining characteristic of N-current (Aosaki and Kasai, 1989; Plummer et al., 1989), which makes it difficult to separate whole-cell N- and L-currents

\footnotetext{
Received Oct. 26, 1990; revised Feb. 15, 1991 ; accepted Feb. 27, 1991.

I thank Paul Ceelen for expert help in cell preparation and Bruce Bean, Jim Huettner, Dinah Sah, Isabelle Mintz, Linda Boland, and Barbara Barres for helpful comments on the manuscript. This work was supported by NIH Grant HL-35034 to B. P. Bean.

Correspondence should be addressed to Bruce P. Bean, Department of Neurobiology, Harvard Medical School, 220 Longwood Avenue, Boston, MA 02115. Copyright (C) 1991 Society for Neuroscience $0270-6474 / 91 / 112259-11 \$ 03.00 / 0$
}

unambiguously. In fact, not all studies have confirmed the existence of multiple types of high-threshold current in DRG cells (Carbone and Lux, 1987; Swandulla and Armstrong, 1988).

Less is known about voltage-dependent calcium currents in the CNS. At least some CNS neurons have calcium currents that seem similar to those in peripheral neurons (e.g., Gray and Johnston, 1987; Yaari et al., 1987; Huang, 1989; Sah, 1990). However, it is still unclear how well the classification developed for peripheral calcium channels (Nowycky et al., 1985b; Fox et al., 1987a,b) encompasses those expressed in central neurons. Here, I have used whole-cell patch-clamp recording (Hamill et al., 1981) to characterize the voltage-dependent calcium currents in Purkinje cells from the cerebellar cortex. These cells are readily accessible and identifiable and have been shown to support calcium-dependent plateau and action potentials in their dendrites (Llinas and Sugimori, 1980a,b; Hounsgaard and Midtgaard, 1988). The currents that underlie these potentials have yet to be characterized fully.

\section{Materials and Methods}

Cell dissociation. Purkinje cells were dissociated using the procedure of Huettner and Baughman (1986). Briefly, small sections of cortex were dissected from the cerebellar vermis of 1-3-week postnatal Long-Evans rats. This is the period during which Purkinje cells extend their dendritic arbors and attain their adult appearance (Altman, 1972). The tissue was cut into small pieces $\left(\approx 0.5-1.0 \mathrm{~mm}^{3}\right)$, incubated in $20 \mathrm{U} / \mathrm{ml}$ papain (Worthington) at $32-36^{\circ} \mathrm{C}$ for $1.5 \mathrm{hr}$, transferred to a solution containing $1 \mathrm{mg} / \mathrm{ml}$ trypsin inhibitor (Type II-O, Sigma) and $1 \mathrm{mg} / \mathrm{ml}$ bovine serum albumin (Sigma), and dissociated by gentle trituration with a fire-polished Pasteur pipette. In some experiments, the incubation medium was changed to one containing a high concentration of potassium (Furshpan and Potter, 1989). Cells were maintained in the enzyme-inhibition solution at room temperature and were used within $10 \mathrm{hr}$. All of the dissociation solutions were $\mathbf{p H} 7.4$.

Propidium iodide labeling. Two rats were injected intramuscularly (hindlimb) with $50-100 \mu$ of $1 \%$ propidium iodide in physiological saline. For each rat, the cerebellar vermis was removed on the day following injection and divided into two parts. One part was dissociated as described above; the other was immediately frozen in cryostat embedding medium (Tissue Tek OCT), sectioned $\left(4\right.$ or $10 \mu \mathrm{m},-16^{\circ} \mathrm{C}$ ), and placed onto gelatin-subbed slides. Cryostat sections were also taken from the cerebellum of a rat perfused with a $2 \%$ paraformaldehyde $/ 0.1$ M phosphate buffer solution (the tissue was equilibrated in a $30 \%$ sucrose $/ 0.1 \mathrm{~m}$ phosphate buffer solution prior to sectioning). Phase and fluorescence microscopy were used to view the dissociated cells and the tissue sections.

Whole-cell recording. Whole-cell recording was performed using a List EPC/7 patch-clamp amplifier (Medical Systems Corp.). Patch pipettes, made from Boralex glass (Rochester Scientific Co.), were coated with Sylgard (Dow Corning Corp.) and fire polished. Resistances with the internal solutions described below were in the range of 1-3 M $\Omega$ (pipettes having greater resistances were used to record from a few cells having unusually small currents). Dissociated cells were placed into the recording chamber containing the bath solution. Following the forma- 
tion of high-resistance seals and attainment of the whole-cell configuration, cells were litted from the bottom of the chamber and exposed to external solution flowing from one of an array of 5-10 gravity-fed microcapillary tubes [constructed according to the design of Yellen (1982) as modified by Friel and Bean (1988)]. Pharmacology experiments were performed by moving the cell between tubes containing external solution with and without drug. Currents elicited by depolarizing potentials (typically delivered at 5 -sec intervals) were filtered at 1,3 , or $10 \mathrm{kHz}(-3$ $\mathrm{dB}$, eight-pole low-pass Bessel filter), digitally sampled at 20-2500- $\mu \mathrm{sec}$ intervals, and stored and analyzed with an LSI 11/73 computer system (Indec Systems, Inc.). Linear leak and capacitance currents were determined by averaging 15 currents elicited by $6-10-\mathrm{mV}$ hyperpolarizing steps (using the holding potential from which subsequent test pulses were given). A scaled version of the averaged current was subtracted from all test currents. Series resistance compensation was used (60-70\% of the measured series resistance was typically compensated for). Cell capacitance was determined from the potentiometer used to null the capacity transient; series resistance was determined using the value of the series conductance potentiometer after the capacitance was nulled. Currents were used in the analysis only if the residual series resistance gave a voltage error of less than $5 \mathrm{mV}$ for peak currents. Command potentials were corrected for the liquid junction potential $(-10 \mathrm{mV})$ between the internal solution and the bath solution in which the pipette current was zeroed before seal formation.

Solutions. The internal solution was composed of (in mM) 9 EGTA, 4.5 $\mathrm{MgCl}_{2}$, $9 \mathrm{HEPES}$, and one of the following: 120 tetraethylammonium (TEA) glutamate (glu), 120 cesium (Cs) glutamate, 108 TEA-glu and 12 Cs-glu, $108 \mathrm{Cs}$-methanesulfonate, or $108 \mathrm{CsF}$ (adjusted to $\mathrm{pH} 7.4$ with TEA-OH or $\mathrm{CsOH}$ ). In order to promote the stability of the currents, $4 \mathrm{~mm} \mathrm{Mg}-\mathrm{ATP}$ and $0.3 \mathrm{~mm}$ GTP (Na or Tris salt) was always included in the pipette solution. In some solutions, an ATP-regenerating system (Forscher and Oxford, 1985) consisting of $14 \mathrm{~mm}$ phosphocreatine [Sigma di(Tris) or disodium salt] and $50 \mathrm{U} / \mathrm{ml}$ creatine phosphokinase (rabbit muscle, Sigma type I) was also included. Creatine phosphokinase interfered with the formation of gigaseals, so a small amount of enzymefree internal solution was sucked into the pipette tip before the pipette was backfilled with the complete internal solution. Concentrated aliquots of solutions containing the various combinations of ATP, GTP, and the ATP-regenerating system were kept frozen at $-70^{\circ} \mathrm{C}$ until being added to the internal solution just prior to use.

Inclusion of an ATP-regenerating solution greatly slows rundown of calcium channel currents in rat DRG neurons (Forscher and Oxford, 1985). In contrast, the high-threshold current in Purkinje cells ran down fairly quickly, even with the ATP-regenerating solution present. (The current in many cells ran down by more than $50 \%$ over the course of about $15 \mathrm{~min}$.) Use of fluoride as the main internal anion greatly enhanced tight-seal formation, and retarded rundown of the high-threshold current, without obviously affecting the properties of the current. [For example, the peak of the high-threshold current $I-V$ relation occurred at an average potential of $-20.2 \pm 1.2 \mathrm{mV}$ when $\mathrm{CsF}$ was in the pipette $(n=16)$, and at $-19.1 \pm 1.2 \mathrm{mV}$ when Cs-methanesulfonate was in the pipcttc $(n=10)$.]

The external solution used for recording was (in mm) $5 \mathrm{BaCl}_{2}$ or $\mathrm{CaCl}_{2}$, $154 \mathrm{TEA}-\mathrm{Cl}, 0$ or $2 \mathrm{MgCl}_{2}, 10$ glucose, and $10 \mathrm{HEPES}$ (adjusted to $\mathrm{pH}$ 7.4 with TEA-OH). Tetraethylammonium (TTX; $1-3 \mu \mathrm{M}$ ) was always included. Seals were formed in a bath solution consisting of (in mM) 2 , 5 , or $10 \mathrm{BaCl}_{2}$ or $\mathrm{CaCl}_{2}$ (usually $5 \mathrm{CaCl}_{2}$ ), $150 \mathrm{NaCl}_{2}, 4 \mathrm{KCl}, 2 \mathrm{MgCl}_{2}$, 10 glucose, and $10 \mathrm{HEPES}$. All experiments were performed at room temperature $\left(20-25^{\circ} \mathrm{C}\right)$.

Drugs. The $\omega$-conotoxin Conus geographus fraction VI-A (GVIA) was purchased from Peninsula Laboratories. It was prepared as $0.5 \mathrm{~mm}$ stock solution in distilled water and stored at $-20^{\circ} \mathrm{C}$. Dihydropyridine (DHP) agonists and antagonists were a gift from Dr. Alexander Scriabine of Miles Laboratories. They were prepared as $10 \mathrm{~mm}$ stock solutions in polyethylene glycol 400 and stored at either $-70^{\circ} \mathrm{C}$ or $-20^{\circ} \mathrm{C}$.

\section{Results}

\section{Purkinje cell identification}

A subset of dissociated rat cerebellar cortical neurons had large somata (15-25 $\mu \mathrm{m}$ in diameter) and single stumps of dendrite (up to $30 \mu \mathrm{m}$ in length). They were chosen for recording because they had the morphological features expected for Purkinje cells missing most of their apical arbor. Although Golgi cells can be as large as Purkinje cells, misidentification should have been minimal because Golgi cells have multiple primary dendrites and are 10 times less numerous than Purkinje cells (Eccles et al., 1967). To confirm the accuracy of the morphological identification, two rats were injected with propidium iodide, a fluorescent dye that selectively labels Purkinje cells in vivo (Borges et al., 1985). Cerebellar tissue from injected animals was taken for cryostat sectioning and for a normal dissociation procedure. In frozen sections, Purkinje cell bodies were brightly labeled by the fluorescent dye. The only other labeled cells in the cerebellar cortex were small-diameter cells scattered throughout the molecular layer. Dispersed cells were viewed under Nomarski and fluorescence optics (Fig. 1 $A, B$ ). Again, the only cells labeled were small-diameter cells and large Purkinje-like cells. In two experiments, $100 \%$ of the cells morphologically identified as Purkinje cells were labeled by propidium iodide $(n=117)$. In one of the dissociations, 6 out of 70 large-diameter cells had multiple processes extending from their somata, which is the morphology expected for Golgi cells. None were labeled with propidium iodide, providing further evidence that Purkinje cells can be identified reliably on the basis of their morphology.

\section{Whole-cell currents \\ Current-voltage relations}

Whole-cell tight-seal recordings were made from morphologically identified Purkinje cells using standard conditions designed to isolate the flow of barium ions through calcium channels. Figure $2 A$ shows currents elicited at several test potentials from two holding potentials. When clicitcd from a holding potential of $-60 \mathrm{mV}$, currents were slowly inactivating; when elicited from $-110 \mathrm{mV}$, currents had an additional transient component. Small depolarizations from the more negative holding potential activated the transient component selectively. The transient and slowly inactivating components will therefore be referred to as the low-threshold and high-threshold components, respectively. Figure $2 B$ shows the difference currents from the traces in $A$, which are predominantly low-threshold currents. Current-voltage relations for the two current components are shown in Figure $2 C$. Although many cells had low- and highthreshold current components, it was unusual to find a cell with a low-threshold current large enough and a high-threshold current stable enough to obtain the data in Figure 2. In contrast, the high-threshold current was readily recorded in isolation, either from cells having no low-threshold component, or from cells held at potentials at which the low-threshold current was inactivated. The high-threshold current typically activated at potentials positive to $-60 \mathrm{mV}$ and reached a peak value of 1986 $\pm 217 \mathrm{pA}$ (range, $672-4034 \mathrm{pA}$ ) at an average potential of -20.0 $\pm 0.9 \mathrm{mV}(n=22)$. The average current density was $102 \pm 17$ $\mathrm{pA} / \mathrm{pF}(n=22)$. There was no obvious correlation between the density of either the high- or low-threshold current and the extent of the dendritic arbor present in the dissociated cells.

\section{Rate of inactivation}

The two current components have very different rates of inactivation. Figure $3 A$ shows the voltage dependence of the decay time constants for the low-threshold currents shown in Figure 2. The decay time constant decreased as the test potential became more depolarized, and reached a limiting value of about $30 \mathrm{msec}$ at $-50 \mathrm{mV}$. In contrast, the high-threshold current decayed only partially during a $2-\mathrm{sec}$ pulse to $-30 \mathrm{mV}$ (Fig. $3 B$ ). The high-threshold current inactivated more rapidly at 
more positive potentials (see Fig. $2 A$; test potential, $-20 \mathrm{mV}$ ), but still much more slowly than the low-threshold current.

\section{Rate of deactivation}

The low- and high-threshold currents can also be distinguished by the rates at which they deactivate when the cell membrane is repolarized following a test pulse. Figure 4 shows traces obtained during sequential test pulses from holding potentials of -110 and $-60 \mathrm{mV}$. Fast sampling rates and a constant repolarization potential were used so that tail-current kinetics could be measured and compared. A step from -60 to $-50 \mathrm{mV}$, expected to activate only the high-threshold component, elicited a small amount of current that deactivated rapidly (Fig. 4A). Nearly all of the current elicited from a holding potential of $-110 \mathrm{mV}$ deactivated much more slowly. Figure $4 B$ shows currents elicited by steps to $-10 \mathrm{mV}$. The tail of the current elicited from $-60 \mathrm{mV}$ decayed rapidly, while the tail of the current elicited from $-110 \mathrm{mV}$ had both fast and slow components. Figure $4 C$ shows exponential fits to expanded tail currents from the difference current of the traces in $B$ (low-threshold current), and from the current elicited from $-60 \mathrm{mV}$ (highthreshold current). The low-threshold current deactivated about an order of magnitude more slowly than the high-threshold current. For both types of current, the time constant of deactivation was voltage dependent, increasing as the repolarization potential became more positive (Fig. $4 D$ ). The dramatic difference between the deactivation kinetics of the low- and highthreshold currents was present at all voltages.

\section{Voltage dependence of inactivation}

As demonstrated in Figures 2 and 4, the low-threshold current was fully inactivated at a holding potential of $-60 \mathrm{mV}$. The dependence of low-threshold current inactivation on holding potential is shown in more detail in Figure 5, $A$ and $C$. The lowthreshold component was determined from peak test-pulse currents (Fig. $5 A$, top) and from tail currents (Fig. $5 A$, bottom). As shown in Figure $5 C$, the normalized values obtained by the two methods showed a similar dependence on holding potential. Inactivation occurred at potentials positive to $-140 \mathrm{mV}$ and was complete at around $-60 \mathrm{mV}$. The low-threshold current inactivation curves obtained from three cells had average midpoint and slope values of $-93 \pm 4 \mathrm{mV}$ and $8.2 \pm 0.4 \mathrm{mV}$, respectively.

A similar method was used to determine the voltage dependence of high-threshold current inactivation in cells having little or no low-threshold current. Examples of currents from such a cell are shown in Figure $5 B$, and the full range of values is plotted as circles in $C$. Inactivation of the high-threshold current extended from approximately -60 to at least $0 \mathrm{mV}$. The midpoint and slope values for this inactivation curve were $-40.7 \mathrm{mV}$ and $9.2 \mathrm{mV}$, respectively. There was a considerable amount of variability in the shape of the high-threshold current inactivation curves obtained from different cells. In eight cells, the midpoint values ranged from -33.9 to $-57.6 \mathrm{mV}$, with a mean value of $-45.8 \pm 3.1 \mathrm{mV}$. The slope values ranged from 6.9 to 19.7 $\mathrm{mV}$, with a mean value of $14.7 \pm 2.1 \mathrm{mV}$.

The high-threshold current elicited from a holding potential of $-120 \mathrm{mV}$ decreased by $73 \%$ over the course of the inactivation curve protocol (see data points at $-90 \mathrm{mV}$ in Fig. $6 \mathrm{C}$ ). The current inactivated at the depolarized holding potentials was not restored by returning to negative holding potentials, even after several minutes. In contrast, the low-threshold cur-
$\mathbf{A}$

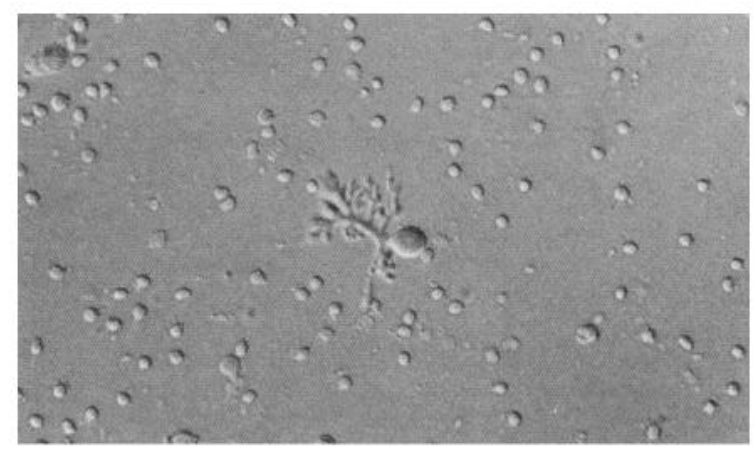

50 m

B
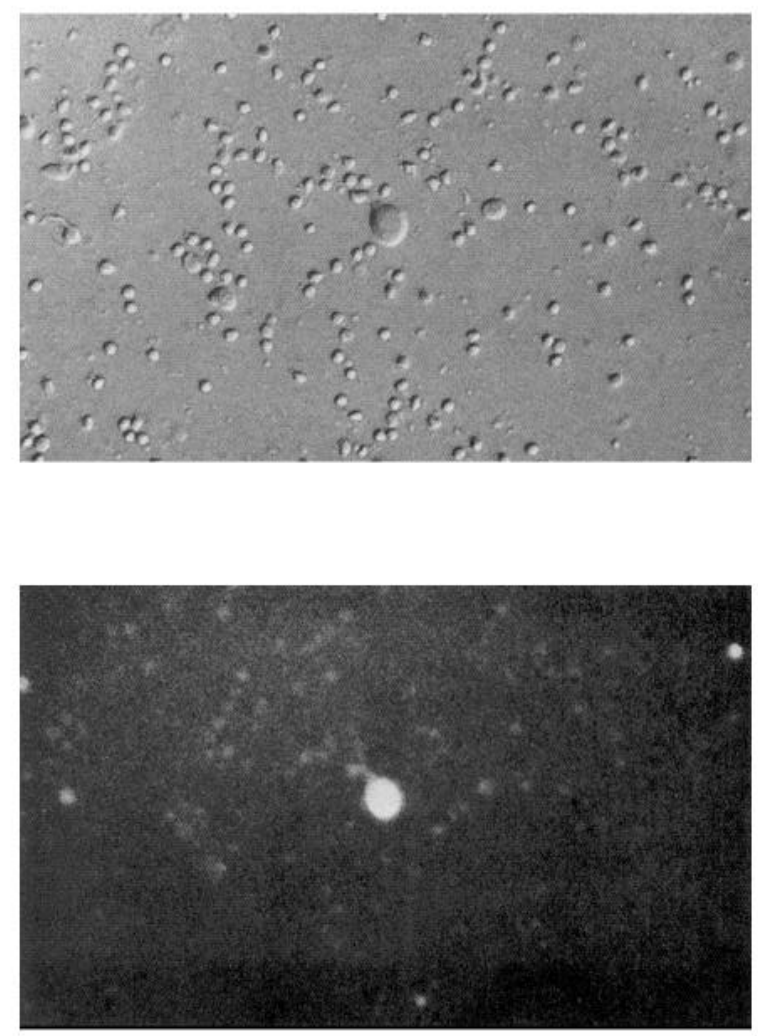

Figure 1. Identification of freshly dissociated Purkinje cells. A, Photomicrograph (Nomarski optics, $100 \times$ ) of cerebellar cells isolated from a rat injected with propidium iodide. In the center is a cell identified as a Purkinje cell because it had a large-diameter cell body and a portion of the apical dendrite. B: Top, Photomicrograph of another presumed Purkinje cell, one representative of those chosen for recording. Bottom, The same field viewed under fluorescence optics, showing that the morphologically identified Purkinje cell was labeled by propidium iodide. 
A

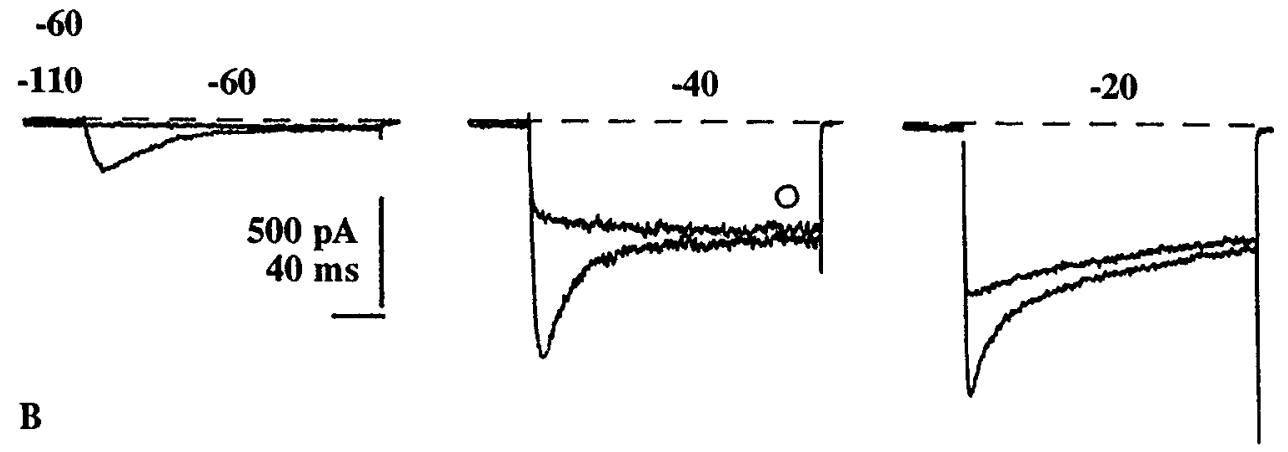

$(-)$

$-60$

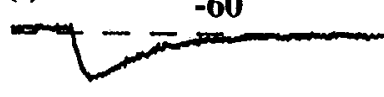

$-40$
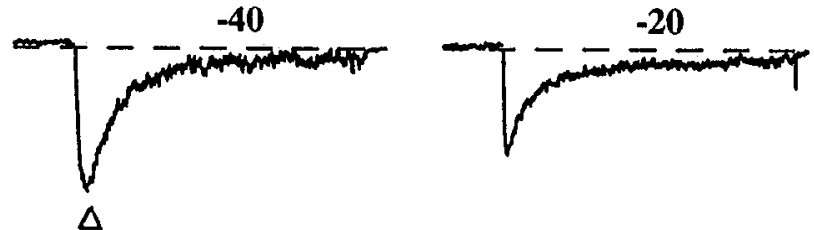

C

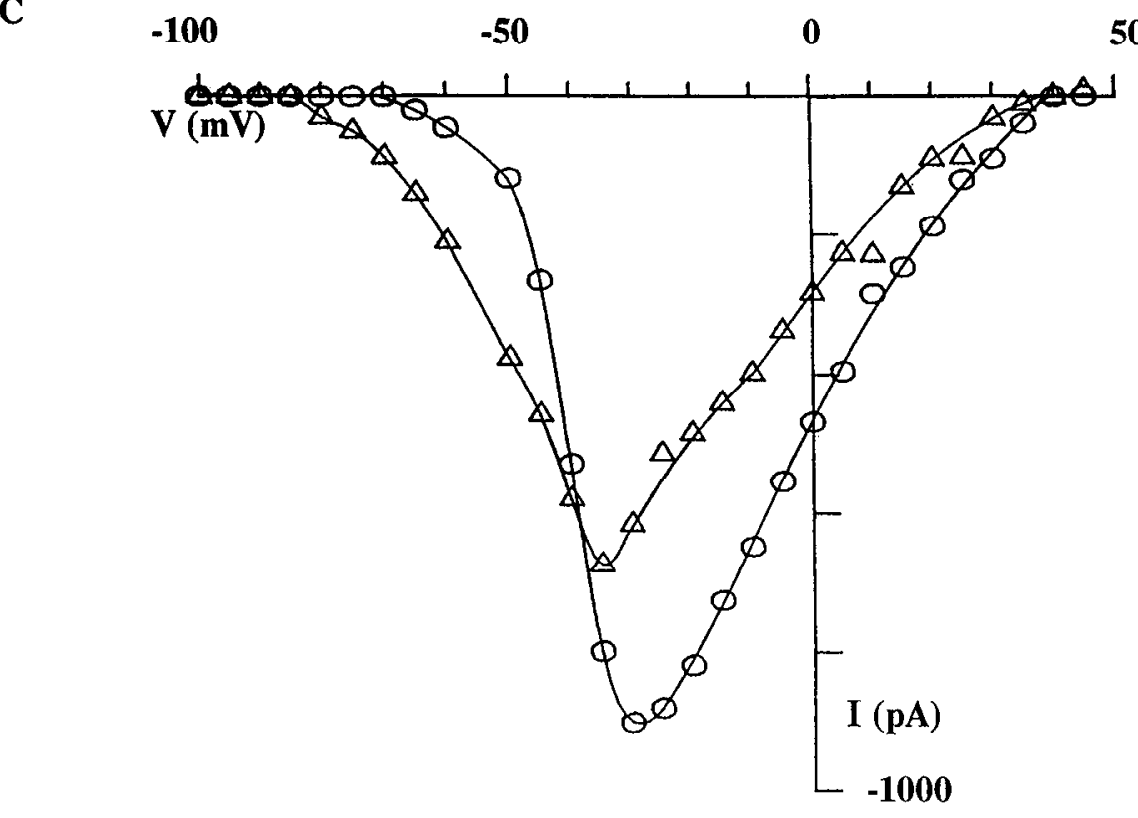

Figure 2. Barium currents in a Purkinje cell that had low- and high-threshold current components. Currents were elicited at test potentials ranging from -100 to $+60 \mathrm{mV}$ by sequential pulses, one from $-110 \mathrm{mV}$ and the other following a 2-sec prepulse to $-60 \mathrm{mV}$. Interstimulus interval, $5 \mathrm{sec}$; sampling rate, $400 \mu \mathrm{sec}$ per sample point. $A$, Currents elicited by steps to $-60,-40$, and $-20 \mathrm{mV}$. Steps from $-60 \mathrm{mV}$ activated only slowly inactivating current; steps from $-110 \mathrm{mV}$ activated both components. $B$, Difference currents from the traces in $A$. They are predominantly transient, low-threshold currents, but also have a minor component of highthreshold current, as a result of a small amount of voltage-dependent inactivation at $-60 \mathrm{mV}$ (see Fig. 5). C, $I-V$ curves for the current elicited from -60 $\mathrm{mV}$ (circles) and the subtraction current (triangles). Cell S44J; capacitance, 21 pF. Internal, CsF; external, $5 \mathrm{~mm} \mathrm{Ba}$.

50

rent decreased by less than $20 \%$ over the course of the inactivation curve protocol (see data points at $-90 \mathrm{mV}$ in Fig. $6 B$ ).

\section{Voltage dependence of activation}

Figure $6 A$ shows activation curves for the low-threshold (triangles) and high-threshold (circles) currents. To determine the voltage dependence of channel activation, tail-current amplitudes were measured at a constant repolarization potential following steps to a series of test potentials. The driving force is the same for all of the tail currents, so the amplitude of the tail current reflects the relative fraction of channels activated by each of the test pulses. The low-threshold current, which was measured after the tail of the high-threshold current had fully deactivated, activated at potentials positive to $-80 \mathrm{mV}$ and reached a saturating value by $0 \mathrm{mV}$. The midpoint of activation for the curve shown in Figure $6 \mathrm{~A}$ is $-46 \mathrm{mV}$, and the slope value is $8.9 \mathrm{mV}$. High-threshold tail currents were measured in cells having no low-threshold current, or by holding cells at a potential at which the low-threshold current was inactivated. The high-threshold current typically activated at potentials positive to $-60 \mathrm{mV}$ and attained a saturating value between 0 and $+10 \mathrm{mV}$. The activation curves have average midpoint and slope values of $-25 \pm 1 \mathrm{mV}$ and $7.5 \pm 0.4 \mathrm{mV}$, respectively $(n=13)$.

Activation and inactivation curves for each type of current were obtained from single cells. For the low-threshold current, there was a small degree of overlap of the two curves in the range from -80 to $-60 \mathrm{mV}$ (Fig. $6 B$ ). The activation and in- 
activation curves for the high-threshold current are shown in Figure $6 C$. The two curves overlap significantly, in the range from -50 to $0 \mathrm{mV}$.

\section{Comparison of calcium and barium currents}

Figure $7 \mathrm{~A}$ shows currents elicited by steps to $-20 \mathrm{mV}$ from a holding potential of $-100 \mathrm{mV}$ in a Purkinje cell moved from the standard barium solution ( $5 \mathrm{~mm}$ ) to one containing calcium ( $5 \mathrm{~mm}$ ). The peak current carried by calcium was significantly smaller than that carried by barium. The tail currents in the two traces have fast and slow phases, indicating the presence of both the low- and high-threshold currents. Only the high-threshold current appeared to be smaller when carried by calcium. When measured near its peak, the tail current was smaller in calcium. However, when measured after deactivation of the high-threshold current, the tail current was essentially unchanged in calcium. Apparently, the low-threshold current is the same size in barium and calcium.

Figure $7 B$ shows current-voltage relations for barium and calcium currents elicited from the same cell using a holding potential of $-80 \mathrm{mV}$. The tail current no longer had a slowly decaying phase (see inset), indicating that the low-threshold current was almost fully inactivated at this holding potential. Compared to the peak of the barium $I-V$ curve, the peak of the calcium $I-V$ curve was about half of the size and was shifted in the depolarizing direction. In three cells, the peak calcium current was an average of $42 \pm 4 \%$ of the size of the peak barium current and was shifted an average of $14 \pm 3 \mathrm{mV}$.

\section{Block by nickel}

In DRG neurons, the T-current is selectively blocked by 100 $\mu \mathrm{M}$ nickel (Fox et al., 1987a). In contrast, the low-threshold current in Purkinje cells appears to be only slightly more sensitive to block by nickel than is the high-threshold current, as shown by the current traces and the corresponding dose-response curves in Figure 8.

\section{Pharmacology of the high-threshold current}

One of the principal ways in which the $\mathrm{L}$ - and $\mathrm{N}$-currents in chick sensory neurons have been distinguished is by their pharmacology. Agents thought to be selective for one or both of the chick DRG high-threshold currents were tested for action on the high-threshold current in rat Purkinje cells.

\section{DHP antagonists}

One of the defining characteristics of the peripheral L-current is its sensitivity to DHP compounds (Nowycky et al., 1985a,b; Fox et al., 1987a,b). Because the high-threshold current in Purkinje cells is kinetically similar to the L-current in peripheral neurons, it was tested for sensitivity to nitrendipine, a DHP antagonist. Cells were held at potentials ranging from -70 to $-90 \mathrm{mV}$ (usually $-70 \mathrm{mV}$ ), and then depolarized to test potentials ranging from -40 to $-10 \mathrm{mV}$ (usually to -30 or -20 $\mathrm{mV}$ ). (More depolarized holding potentials were not used because calcium currents became unstable when the cells were held positive to $-50 \mathrm{mV}$ for seconds.) The current elicited by the test potential was measured before, during, and after the application of $10 \mu \mathrm{M}$ nitrendipine. In each of the cells tested, nitrendipine had little effect on the high-threshold current (average decrease, $7.9 \pm 1.8 \% ; n=16$; Fig. $9 A$ ). The small amount of block by nitrendipine was usually not fully reversible and could not be clearly distinguished from current rundown in some
$\mathbf{A}$

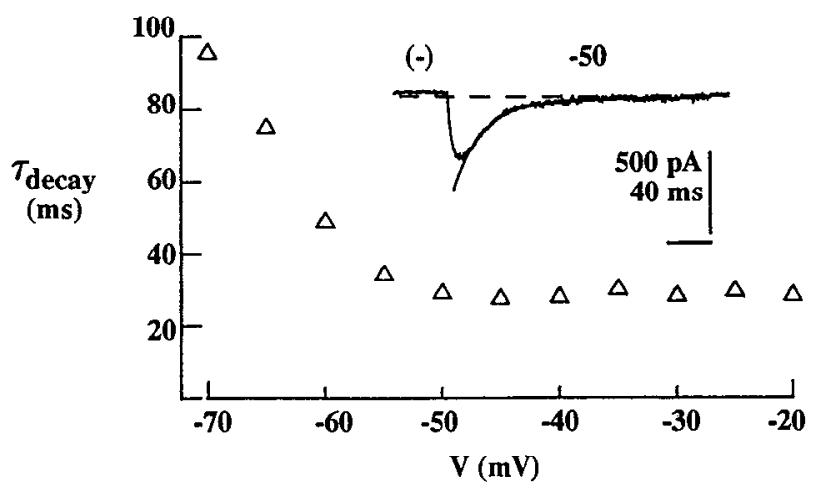

B

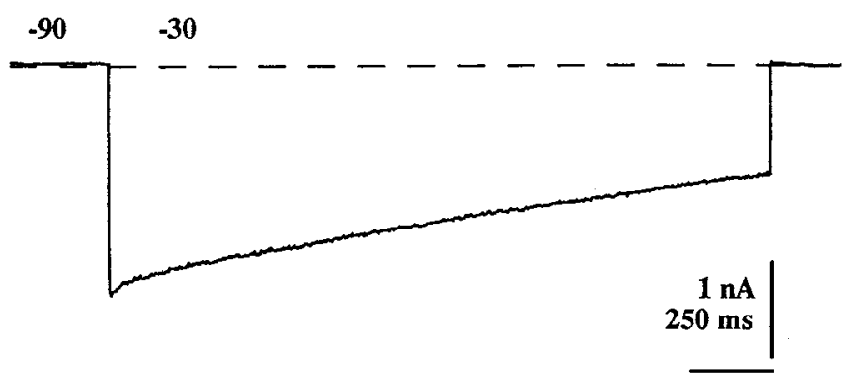

Figure 3. Inactivation rates of the low- and high-threshold components. $A$, Voltage dependence of the time constant of decay for the lowthreshold current. Values are from least-squares exponential fits to the falling phase of the difference currents from Figure 2 (example in inset). When currents did not decay completely, fits were to the level of the steady inward current. $B$, Inactivation during a 2 -sec pulse in a cell having predominantly high-threshold current. Cell Q94B; capacitance, $27 \mathrm{pF}$. Internal, Cs-methanesulfonate; external, $5 \mathrm{~mm} \mathrm{Ba}$.

cells. In three additional cells, $1 \mu \mathrm{M}$ nimodipine blocked the high-threshold current by an average of $7.0+0.4 \%$. Nitrendipine and nimodipine blocked a significant amount of the highthreshold current elicited from $-70 \mathrm{mV}$ in rat DRG cells, suggesting that the lack of effect on the Purkinje cell current was not primarily due to the voltage dependence of DHP action.

\section{$B A Y K 8644$}

Given the kinetic similarity between the Purkinje cell highthreshold current and the peripheral L-current, it seemed surprising that nitrendipine had such a small effect. To test further the sensitivity of the high-threshold current to DHPs, the L-channel agonist BAY K8644 was used. In most of the cells tested (19 out of 23), a small but significant fraction of the tail current was slowed in the presence of $1 \mu \mathrm{M}$ BAY K8644. The drug increased the size of the high-threshold current when the current was activated by small depolarizations, but had little effect near the peak of the current-voltage relation. When the holding potential was -80 or $-90 \mathrm{mV}$, currents elicited at -50 or $-40 \mathrm{mV}$ were increased by an average of $29 \pm 15.2 \%(n=$ 7 ; Fig. $9 D$ ), whereas currents elicited by steps to potentials ranging from -30 to $-10 \mathrm{mV}$ were decreased by an average of 7.6 $\pm 3.8 \%(n=11$; Fig. $9 C)$. The relative resistance of the Purkinje cell high-threshold current to DHPs suggested that the major portion of the current is pharmacologically distinct from the peripheral L-type current. 
A

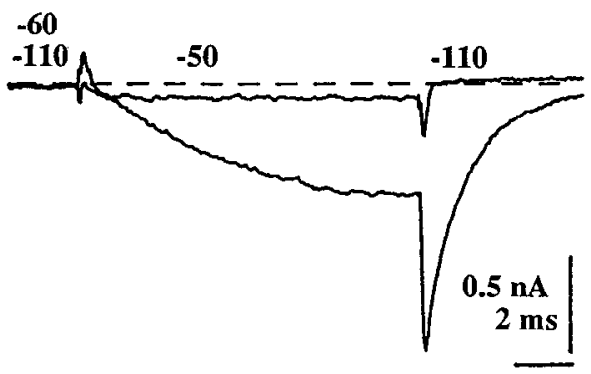

C
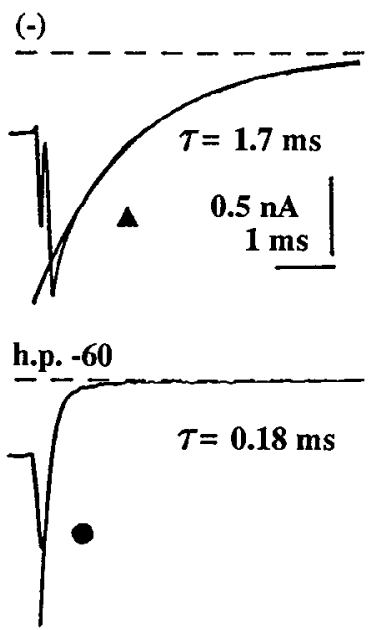

D
B
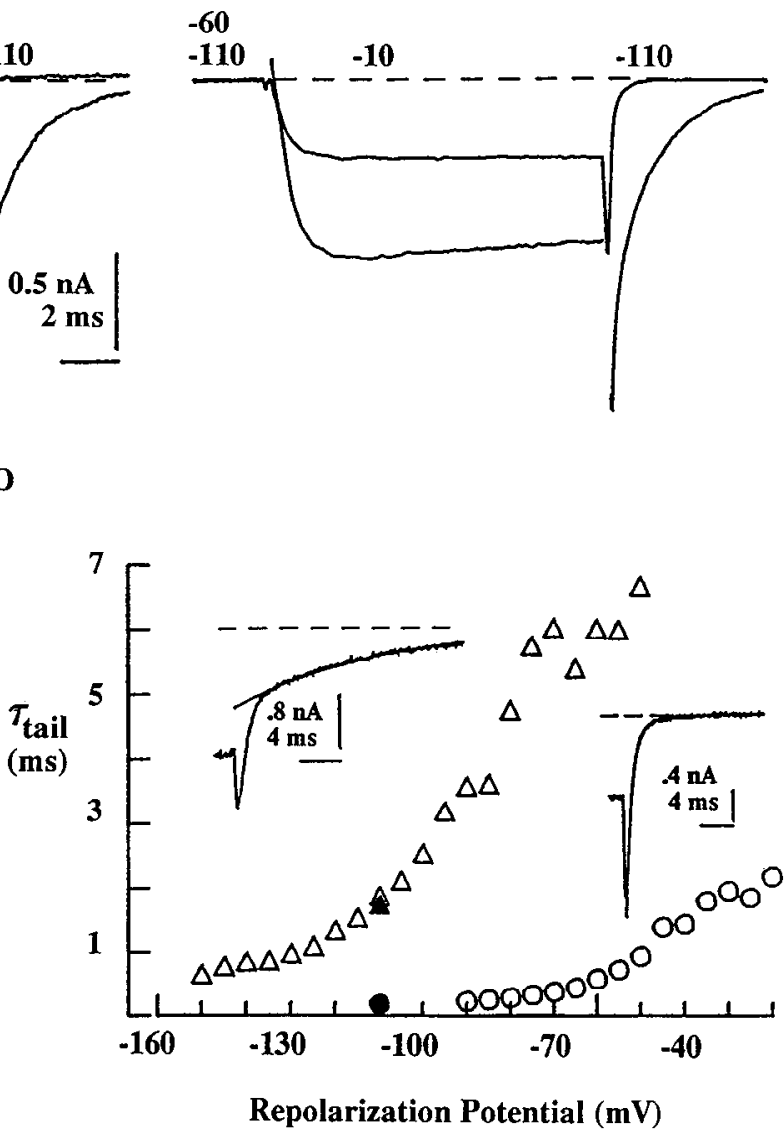

Figure 4. Deactivation rates of the low- and high-threshold components. $A$, Currents elicited by sequential 12 -msec pulses to $-50 \mathrm{mV}$ from -110 $\mathrm{mV}$ and following a 2-sec prepulse to $-60 \mathrm{mV}$. Repolarization potential, $-110 \mathrm{mV}$; sampling rate, $20 \mu$ sec per point. The tail of the difference current of the two traces was well fit by a single exponential having a time constant of $1.66 \mathrm{msec}$ (not shown). Cell S44J; capacitance, 21 pF. $B$, Currents elicited by steps to $-10 \mathrm{mV}$ by the same protocol in the same cell. $C$, Expanded tail currents from the difference current of the traces in $B(t o p)$ and from the $-60-\mathrm{mV}$ trace in $B($ bottom). Tail currents were fit with nonlinear least-squares exponentials. The difference tail was fit over the range from $560 \mu \mathrm{sec}$ following repolarization to the end of the trace, assuming that the current returned to the 0 current level. Time constant of deactivation was $1.68 \mathrm{msec}$. The $-60-\mathrm{mV}$ tail current was fit over a $200-\mu \mathrm{sec}$ range starting $300 \mu \mathrm{sec}$ after repolarization (baseline was the 0 current level). Time constant of deactivation was $0.18 \mathrm{msec}$. h.p., holding potential. $D$, Dependence of the time constant of deactivation of the low-threshold current (triangles) and high-threshold current (circles) on the repolarization potential. For the low-threshold current, steps to a test potential of $-40 \mathrm{mV}$ from a holding potential of $-110 \mathrm{mV}$ were followed by repolarizations to potentials ranging from -150 to $-50 \mathrm{mV}$. Interstimulus interval, $1 \mathrm{sec}$. A nonlinear least-squares exponential was fit to the slow phase of each tail current (starting from 440 to $700 \mu \mathrm{sec}$ after repolarization to the end of the trace), assuming the current decayed to the 0 current level. The sample trace in the inset to the left had a repolarization potential of $-90 \mathrm{mV}$. The solid triangle is the value from $C$, top, which is from a different trace from the same cell. Values for the high-threshold current were obtained from a different cell. Steps to a test potential of $-20 \mathrm{mV}$ from a holding potential of $-80 \mathrm{mV}$ were followed by repolarizations to potentials ranging from -90 to $-20 \mathrm{mV}$. Tail currents were fit starting $200 \mu \mathrm{sec}$ after repolarization. At repolarization potentials of $-50 \mathrm{mV}$ and above, tail currents were fit assuming a steady level of inward current (not attained during the trace). The sample trace in the inset to the right had a repolarization potential of $-90 \mathrm{mV}$. The solid circle is the value from C, bottom. Cell S43E; capacitance, $22 \mathrm{pF}$. Internal, CsF; external, 5 mм Ba.

\section{$\omega$-conotoxin}

Is this novel current more closely related to the second class of high-threshold calcium current in peripheral neurons, the $\mathrm{N}$-current? This possibility was tested with the use of $\omega$-conotoxin (Olivera et al., 1984), a peptide toxin shown to produce a persistent block of the $\mathrm{N}$-current in peripheral neurons (Kasai

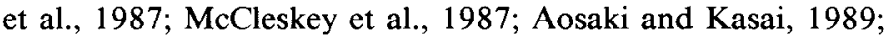
Plummer et al., 1989). The high-threshold current in Purkinje cells was insensitive to $3 \mu \mathrm{M} \omega$-conotoxin. Currents elicited by depolarizations to -30 or $-20 \mathrm{mV}$ from a holding potential of $-70 \mathrm{mV}$ were blocked by an average of only $6.4 \pm 1.0 \%(n=$
17; Fig. $9 B$ ). In order to check the potency of the $\omega$-conotoxin, several experiments were performed on DRG and Purkinje cells isolated from the same animals. Under identical recording conditions, $\omega$-conotoxin solutions that had little effect on the highthreshold current in Purkinje cells invariably blocked a large fraction of the high-threshold current in DRG cells.

\section{Discussion}

A subset of Purkinje cells dissociated from the rat cerebellar vermis had a low-threshold current similar to the T-type current characterized in peripheral neurons. All of the Purkinje cells had a high-threshold current that inactivated slowly, like the 
A

t.p. $=-\mathbf{5 0}$
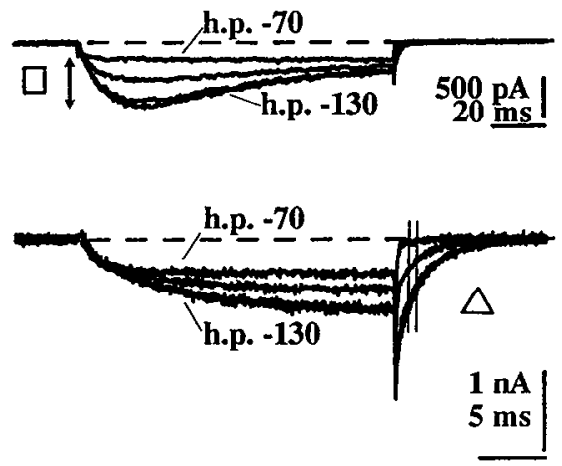

B

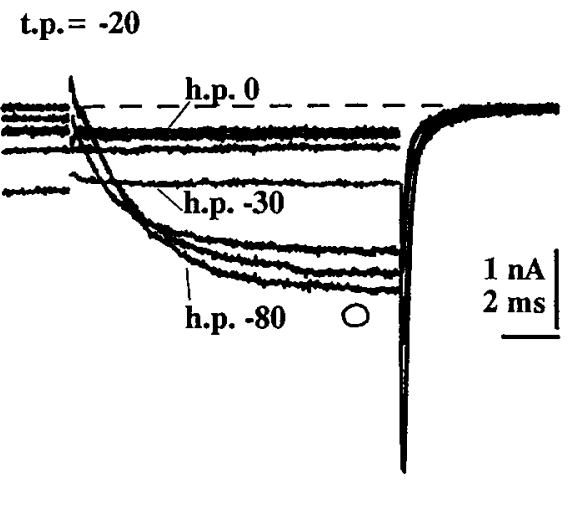

C

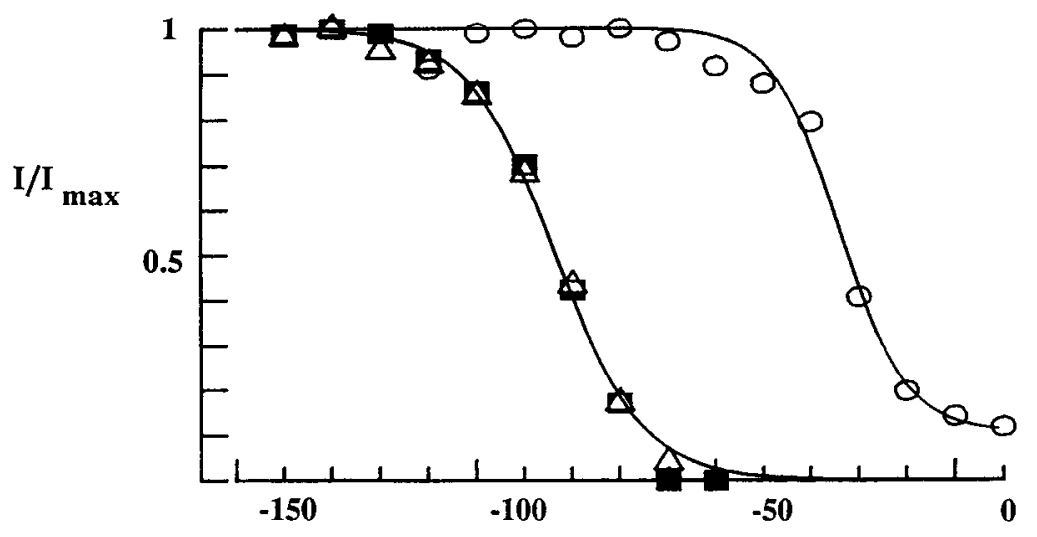

Holding Potential (mV)

Figure 5. Inactivation of the current components with holding potential. $A$, Low-threshold current. From a holding potential of $-120 \mathrm{mV}, 2$-sec prepulses $(-150$ through $-60 \mathrm{mV}$ ) were followed by $120-\mathrm{msec}$ (top traces) or $24-\mathrm{msec}$ (bottom traces) test pulses to $-50 \mathrm{mV}$. The first and every subsequent fourth prepulse was to the steady holding potential of $-120 \mathrm{mV}$, to test for changes in the control level of current. Traces shown had prepulse potentials ranging from -130 to $-70 \mathrm{mV}$ in $20-\mathrm{mV}$ intervals. Interstimulus interval, 10 sec. $t . p$., test potential; $h . p$., holding potential. $B$, High-threshold current inactivation in a cell having no low-threshold current. From a holding potential of $-90 \mathrm{mV}, 2-\mathrm{sec}$ prepulses $(-120$ through $0 \mathrm{mV}$ ) were followed by $12-\mathrm{msec}$ pulses to $-20 \mathrm{mV}$. Every fourth pulse was to $-90 \mathrm{mV}$. Interstimulus interval, 10 sec. Traces shown had prepulses to $-80,-60,-40,-30,-20,-10$, and $0 \mathrm{mV}$. Prepulse potentials positive to $-60 \mathrm{mV}$ elicited steady inward current, which was maximal at $-30 \mathrm{mV}$. $C$, Currents normalized to the largest current measured during each protocol. Squares, low-threshold current measured as the difference between the peak current and the noninactivating current elicited from a holding potential of $-70 \mathrm{mV}$ (120-msec pulses in $A$ ); triangles, low-threshold current averaged over a $0.4-\mathrm{msec}$ interval that began $1.2 \mathrm{msec}$ after the end of the test pulse (vertical lines in $A$, bottom), when the low-threshold current was fully deactivated (24-msec pulses in $A$, bottom); circles, peak current values during the test pulse for the highthreshold currents (from $B$ ). Smooth curves were fit to the data points accofding to $I=I_{\max } /\left[1+\exp \left(V_{h}-V_{t_{2}}\right) / k\right]+I_{\text {constant }}$. In fitting each of the curves, only one of the values obtained from the holding potential of $-120 \mathrm{mV}$ was used. For simplicity, the remaining points are not shown here (see Fig. $6 B, C$ ). Triangles, $V_{1 / 2}=-93 \mathrm{mV}, k=9.2 \mathrm{mV}, I_{\text {con }}=0\left(I_{\max }\right.$ was $\left.0.95 \mathrm{nA}\right)$; squares (curve not shown), $V_{1 / 2}=-94 \mathrm{mV}, k=8.3 \mathrm{mV}, I_{\text {con }}=$ $0\left(I_{\max }\right.$ was $\left.0.84 \mathrm{nA}\right)$; circles, $V_{y_{1}}=-34 \mathrm{mV}, k=6.9 \mathrm{mV}, I_{\text {con }}=0.11\left(I_{\max }\right.$ was $\left.2.37 \mathrm{nA}\right)$. Low-threshold current $(A)$ : cell S36C; capacitance, $39 \mathrm{pF}$. High-threshold current $(B)$ : cell S43E; capacitance, $22 \mathrm{pF}$. Internal, CsF; external, $5 \mathrm{~mm}$ Ba.

L-current in chick DRG cells (Fox et al., 1987a). However, DHP antagonists blocked less than $10 \%$ of the high-threshold current in Purkinje cells, indicating that greater than $90 \%$ of the highthreshold current was pharmacologically distinct from L-current.

\section{The DHP-resistant high-threshold current is not $N$-current}

The high-threshold current inactivates at a much slower rate than the N-current in chick DRG cells (Fox et al., 1987a). This docs not clearly distinguish the Purkinje cell current from the $\mathrm{N}$-current, though, because the rate of $\mathrm{N}$-current inactivation can be variable, both between cell types (Hirning et al., 1988) and within a given cell type (Kasai and Aosaki, 1988; Aosaki and Kasai, 1989; Kongsamut et al., 1989; Plummer et al., 1989). A more reliable difference is that the chick DRG N-current, but not the Purkinje cell high-threshold current, undergoes a significant amount of inactivation over the range of holding potentials from -60 to $-100 \mathrm{mV}$ (Fox et al., 1987a). Another clear difference is that the high-threshold current in Purkinje cells is insensitive to $\omega$-conotoxin (Olivera et al., 1984), whereas the N-current in chick DRG cells is virtually completely blocked by it (Kasai et al., 1987; McCleskey et al., 1987; Aosaki and Kasai, 1989). 
A

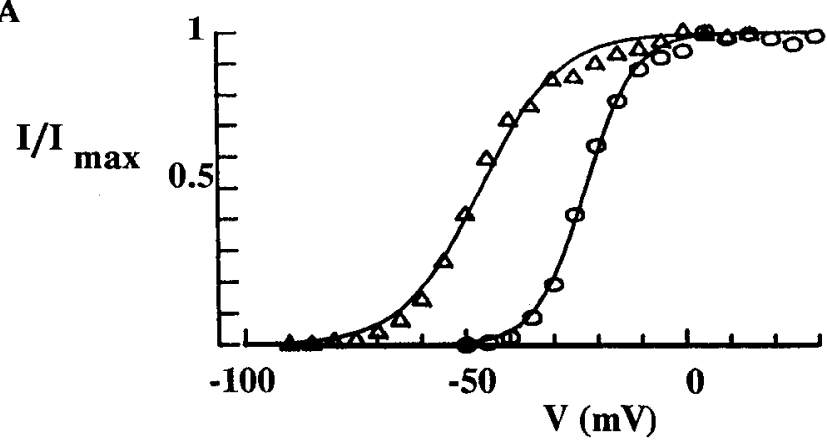

B

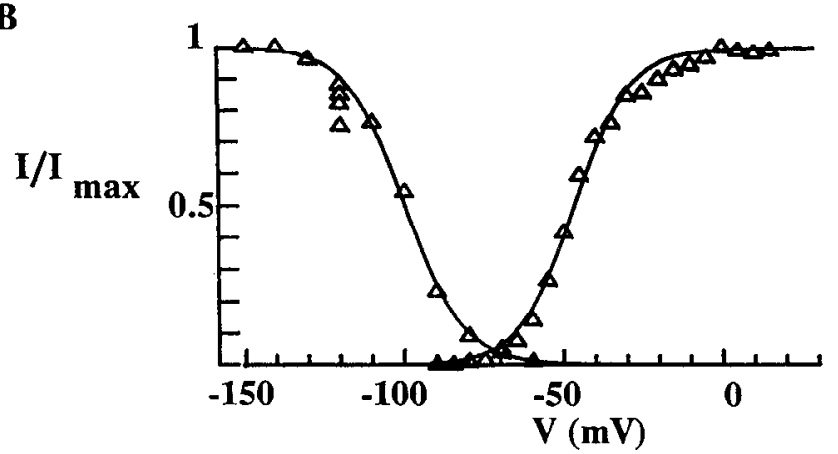

C

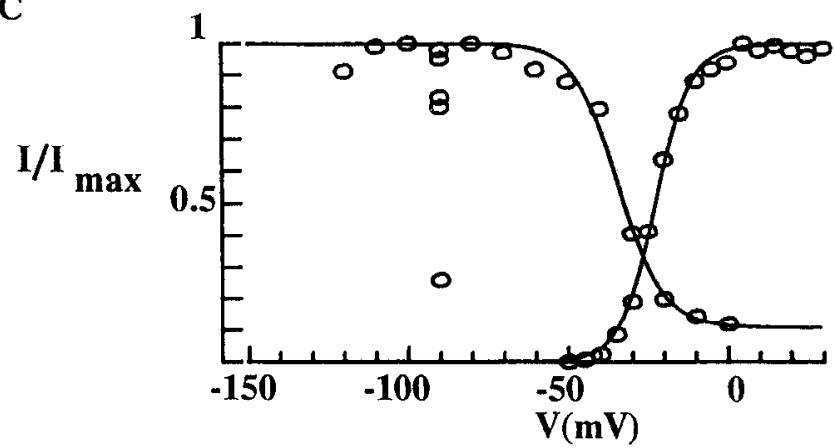

Figure 6. A, Activation curves for the low-threshold (triangles) and high-threshold (circles) currents. Low-threshold currents, elicited at different test potentials from a holding potential of $-110 \mathrm{mV}$, were measured over a $0.2-\mathrm{msec}$ period starting $1.6 \mathrm{msec}$ after repolarization. Cell S44J; capacitance, $21 \mathrm{pF}$. High-threshold currents, elicited from -80 $\mathrm{mV}$, were measured over a $0.1-\mathrm{msec}$ period starting $0.3 \mathrm{msec}$ after repolarization. Cell S43E; capacitance, $22 \mathrm{pF}$. Smooth curves were fit to normalized data points according to $I=I_{\max } /\left[1+\exp \left(-\left(V_{h}-V_{1_{1 / 2}}\right) /\right.\right.$ $k)$. Triangles, $V_{1 / 2}=-46 \mathrm{mV}, k=8.9 \mathrm{mV}\left(I_{\max }\right.$ was $\left.1.27 \mathrm{nA}\right)$; circles, $V_{1 / 2}=-22 \mathrm{mV}, k=5.8 \mathrm{mV}\left(I_{\max }\right.$ was $\left.2.30 \mathrm{nA}\right)$. B. Overlap of the activation and inactivation curves for the low-threshold current. Activation curve is as in $A$. The inactivation curve was obtained by measuring tail currents (over $0.2 \mathrm{msec}$, starting $1 \mathrm{msec}$ after repolarization) of traces elicited at $-40 \mathrm{mV}$ following different prepulse potentials. The holding potential was $-120 \mathrm{mV}$; every fourth pulse was to this potential (as explained in Fig. 5). $V_{1 / 2}=-100 \mathrm{mV}, k=9.0 \mathrm{mV}, I_{\text {con }}=0\left(I_{\max }\right.$ was $1.46 \mathrm{nA}$ ). The current decreased by $16 \%$ over the course of the protocol. Cell S44J; capacitance, $21 \mathrm{pF}$. $C$, Overlap of the activation and inactivation curves for the high-threshold current. The current decreased by $73 \%$ over the course of the protocol. Activation curve is as in $A$; inactivation curve is as in Figure $5 C$. Cell S43E; capacitance, $22 \mathrm{pF}$. Internal, CsF; external, $5 \mathrm{~mm} \mathrm{Ba}$.
A

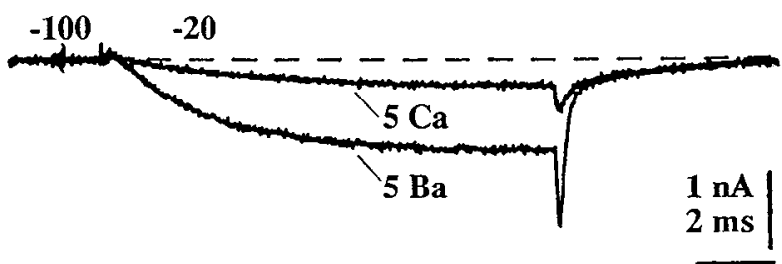

$\mathbf{B}$

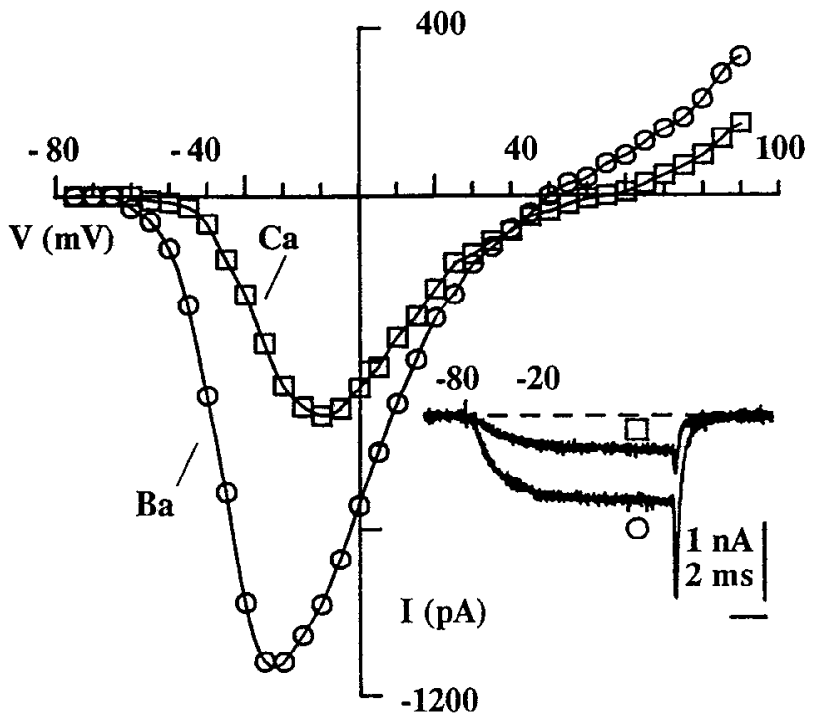

Figure 7. Comparison of $\mathrm{Ca}$ and Ba currents. $A$, Current carried by 5 mм Ca was measured $15 \mathrm{sec}$ after transfer from the $5 \mathrm{~mm}$ Ba solution. (It recovered fully upon return to $\mathrm{Ba}$.) The tail current decreased significantly in $\mathrm{Ca}$ when measured near its peak (over $0.1 \mathrm{msec}$, starting $0.2 \mathrm{msec}$ after repolarization), but remained essentially unchanged when measured after the high-threshold current had decayed (over $0.2 \mathrm{msec}$ starting $1.6 \mathrm{msec}$ after repolarization). Cell S40B; capacitance, $32 \mathrm{pF}$. $B$, Full $I-V$ curves for $\mathrm{Ca}$ and $\mathrm{Ba}$ currents elicited from $-80 \mathrm{mV}$ in the same cell, when the low-threshold current was almost fully inactivated (see traces in inset). $5(\mathrm{mM}) B a: I_{\text {peak }}=1.12 \mathrm{nA}, V_{\text {peak }}=-22 \mathrm{mV}, E_{\text {rev }}$ $=150 \mathrm{mV} .5(\mathrm{mM}) \mathrm{Ca}: I_{\text {peak }}=0.53 \mathrm{nA}, V_{\text {peak }}=-9 \mathrm{mV}, E_{\text {rev }}=+70$ $\mathrm{mV}$. Internal, CsF.

\section{Potential function of the high-threshold current}

Purkinje cells in slices have been shown to support high-threshold calcium-dependent plateau and action potentials (Llinas and Sugimori, 1980a,b; Hounsgaard and Midtgaard, 1988) that are not sensitive to DHP agonists (Llinas et al., 1989a) or antagonists, or to $\omega$-conotoxin (Llinas et al., 1989b). Thus, it is possible that the class of channels underlying the major component of the high-threshold current in the freshly dissociated cells produces the calcium-dependent potentials in the Purkinje cells in the slice preparations. If so, the channels are expected to be blocked by a fraction of funnel web spider toxin (FTX) that blocks the calcium-dependent potentials in Purkinje cells (Llinas et al., 1989b). It will be interesting to see whether the $\omega$-conotoxin- and nitrendipine-resistant portion of the high-threshold current in Purkinje cells flows through FTX-sensitive channels, and whether these channels are similar to the "P" channels isolated from solubilized cerebellar membranes and recorded following reconstitution into lipid bilayers (Llinas et al., 1989b).

Under the recording conditions of the present study, the activation and inactivation curves of the high-threshold current 
A
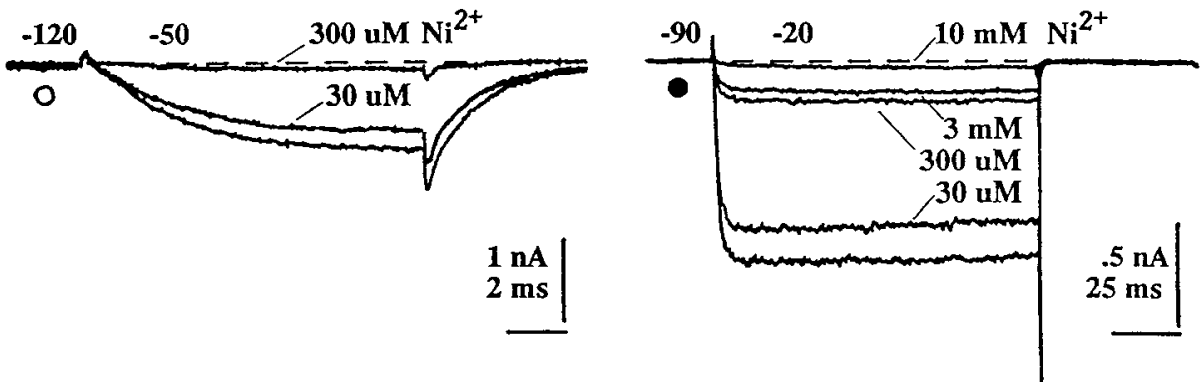

C

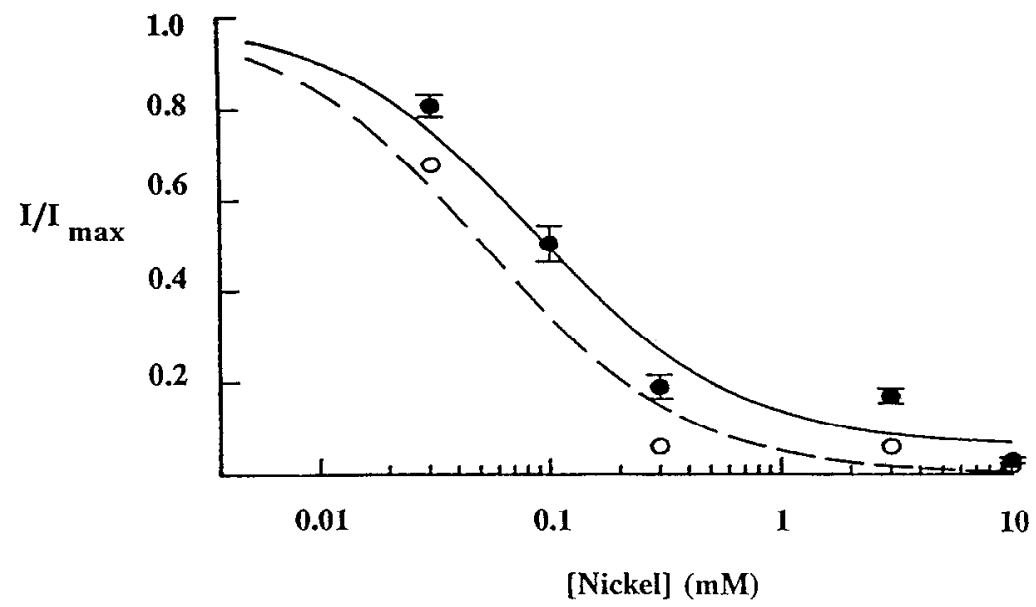

A

$-70$ $-30$

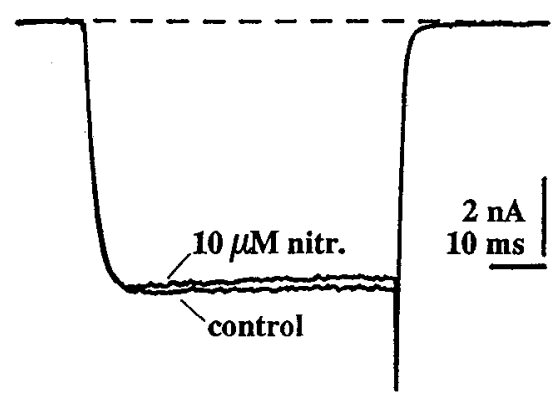

C

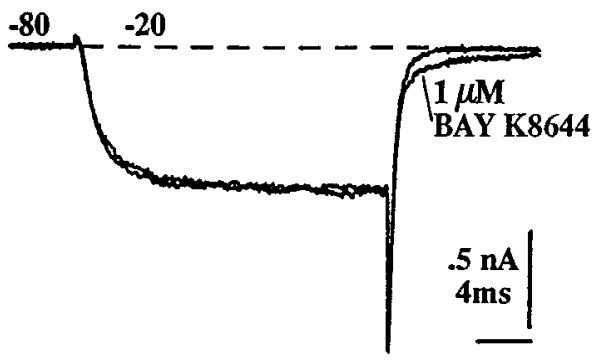

B

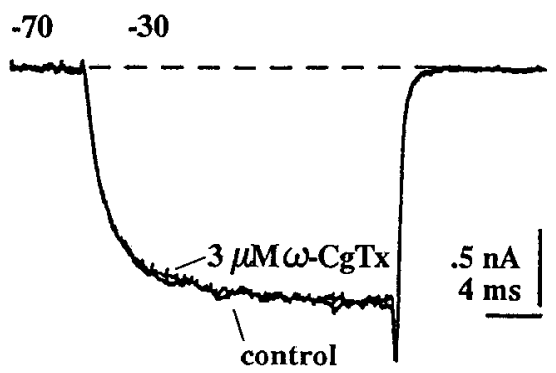

D

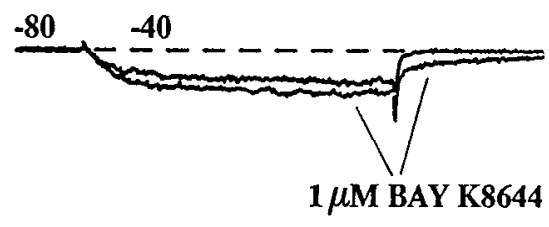

Figure 8. Block of Ba currents by nickel ions. $A$, Currents elicited at -50 $\mathrm{mV}$ from $-120 \mathrm{mV}$. They were predominantly low-threshold currents, as indicated by the slowly decaying tail currents. Cell S44J; capacitance, 21 pF. $B$, High-threshold currents in a cell with very little low-threshold current. Cell S44I; capacitance, $25 \mathrm{pF}$. $C$, Dose-response curves for currents in the presence of various concentrations of nickel, normalized to the control level of current. Open circles, single values for the transient current averaged over the period from 1 to 1.2 msec after repolarization from the cell shown in $A$. The broken curve fit to these points gives a $K_{d}$ of $52 \mu \mathrm{M}$. Solid circles, values of peak high-threshold current (mean \pm SEM for three to seven cells). The solid curve fit to the points gives a $K_{d}$ of $87 \mu \mathrm{M}$. Internal, CsF; external, $5 \mathrm{~mm} \mathrm{Ba}$.
Figure 9. Pharmacology of the highthreshold current. $A$, Current recorded in control solution and $15 \mathrm{sec}$ after transfer to a solution containing $10 \mu \mathrm{M}$ nitrendipine. Cell S02A; capacitance, $35 \mathrm{pF}$. $B$, Current recorded in control solution and $10 \mathrm{sec}$ after transfer to a solution containing $3 \mu \mathrm{M} \omega$-conotoxin Cell S05D; capacitance, 22 pF. C, Currents recorded in control solution and $15 \mathrm{sec}$ after transfer to solution containing $1 \mu \mathrm{M}$ BAY K8644. Peak current changed little, while a small but significant percentage of the tail current was slowed. Cell S43C; capacitance, $21 \mathrm{pF}$. $D$, Traces taken from sequential $I-V$ curves in control solution and solution containing $1 \mu \mathrm{M}$ BAY K8644. Peak current increased by $37 \%$ in BAY K8644, and a large percentage of the tail current was slowed. Calibration is as in $C$. Cell S43D; capacitance, $19 \mathrm{pF}$. Cells in $A$ and $B$ had internal Cs-methanesulfonate and external $5 \mathrm{~mm}$ Ba. Cells in $C$ and $D$ had internal CsF and external 5 тм Ba. 
overlapped significantly (over the range from $-50 \mathrm{mV}$ to at least $0 \mathrm{mV}$ ). If there is a similar overlap between the activation and inactivation curves under physiological ionic conditions, the channels underlying the high-threshold current could contribute a steady influx of calcium over a fairly broad range of potentials.

\section{Localization of the high-threshold channels: comparison to results on cerebellar slices and cultures}

Electrophysiological (Llinas and Sugimori, 1980a,b; Hounsgaard and Midtgaard, 1988) and calcium-imaging (Ross and Werman, 1987; Tank et al., 1988) studies on cerebellar slice preparations have provided evidence that the high-threshold calcium channels in Purkinje cells are preferentially located in the dendrites. The regional distribution of calcium channels has been reported to occur even in Purkinje cells cultured from immature rats (Hockberger et al., 1989). The freshly dissociated Purkinje cells in the present study had only short segments of apical dendrite, so it was somewhat surprising that the highthreshold calcium currents were so large (current densities above $100 \mathrm{pA} / \mathrm{pF}$ of cell capacitance were common). Although it is possible that the currents recorded from freshly dissociated cells arose only or mainly from dendritic channels, there did not appear to be a correlation between current amplitude and the amount of dendrite present. The apparent somatic location of the calcium channels in the freshly dissociated cells could be an artifact. For example, some of the proximal dendritic membrane could have been absorbed into the soma during the dissociation. It is also possible that calcium channels anchored in the dendritic membrane could have been freed for migration by the dissociation procedure. However, it is also possible that Purkinje cell bodies have calcium channels in vivo, and that the indirect methods used in the earlier studies failed to detect them. Recent studies support this idea. On-cell patch recording provided direct evidence that low- and high-threshold calcium channels are located on the somata of Purkinje cells cultured from embryonic rats (Hirano and Hagiwara, 1989). An immunocytochemical study on sections of adult rat cerebellum provided evidence that DHP-sensitive calcium channels are concentrated on Purkinje cell somata (Ahlijanian et al., 1990).

Unless the dissociation procedures promoted the migration of ion channels in the plasma membrane, it is unlikely that channels normally restricted to the distal dendrites would have been recorded from the freshly isolated cells. Recent studies have provided evidence for high-threshold, transient (N-like) currents in the dendrites of cultured rat Purkinje cells (Bossu et al., 1989a). Such a current was not prominent in the freshly dissociated Purkinje cells. A possible explanation is that N-type channels are normally concentrated in the distal dendrites of Purkinje cells. However, culture conditions have been shown to influence dramatically the complement of calcium channels expressed by Purkinje cells (Bossu et al., 1989a), so it is possible that cultured Purkinje cells express a different mixture of calcium channel types than do cells in vivo.

\section{The low-threshold current}

Low-threshold calcium currents, recorded from a subset of the freshly dissociated Purkinje cells in the present study, have also been recorded from cultured embryonic rat Purkinje cells using whole-cell (Bossu et al., 1989a) and single-channel (Bossu et al., 1989b; Hirano and Hagiwara, 1989) patch-clamp techniques. The function of this current in Purkinje cells is not known. One possibility is that the low-threshold channels could contribute a steady influx of calcium at relatively hyperpolarized potentials, if the overlap of the activation and inactivation curves is similar under experimental and physiological conditions. No evidence has been found for a contribution of a low-threshold, transient calcium current to the voltage responses recorded from Purkinje cells in slice preparations (Llinas and Sugimori, 1980a,b; Hounsgaard and Midtgaard, 1988).

\section{Conclusion}

While the role played by the low-threshold calcium current in intact Purkinje cells is unclear, the high-threshold current is a likely candidate for the current that underlies the calcium-dependent plateau and action potentials generated in Purkinje cell dendrites. The high-threshold current appears to include a small amount of DHP-sensitive L-current, but to consist predominantly of a current that is distinct from $\mathrm{L}$ - and $\mathrm{N}$-currents characterized in peripheral neurons. Whether this novel current has a counterpart in peripheral and other central neurons remains to be resolved. It will be interesting to study further the biophysical and pharmacological properties and the modulation of this novel current.

\section{References}

Ahlijanian MK (1990) Subunit structure and localization of dihydropyridine-sensitive calcium channels in mammalian brain, spinal cord, and retina. Neuron 4:819-832.

Altman J (1972) Postnatal development of the cerebellar cortex in the rat. II. Phases in the maturation of Purkinje cells and of the molecular layer. J Comp Neurol 145:399-464.

Aosaki T, Kasai H (1989) Characterization of two kinds of highvoltage-activated $\mathrm{Ca}$-channel currents in chick sensory neurons: differential sensitivity to dihydropyridines and $\omega$-conotoxin GVIA. Pfluegers Arch 414:150-156.

Bean BP (1989) Classes of calcium channels in vertebrate cells. Annu Rev Physiol 51:367-384.

Borges LF, Elliott PJ, Gill R, Iversen SD, Iversen LL (1985) Selective extraction of small and large molecules from the cercbrospinal fluid by Purkinje neurons. Science 228:346-348.

Bossu J-L, Feltz A, Thomann JM (1985) Depolarization elicits two distinct calcium currents in vertebrate sensory neurons. Pfluegers Arch 403:360-368.

Bossu J-L, DuPont J-L, Feltz A (1989a) Calcium currents in rat cerebellar Purkinje cells maintained in culture. Neuroscience 30:605617.

Bossu J-L, Fagni L, Feltz A (1989b) Voltage-activated calcium channels in rat Purkinje cells maintained in culture. Pfluegers Arch 414: 92-94.

Carbone E, Lux HD (1984a) A low voltage-activated calcium conductance in embryonic chick sensory neurones. Biophys J 46:413418.

Carbone E, Lux HD (1984b) A low voltagc-activatcd, fully inactivating Ca channel in vertebrate sensory neurones. Nature 310:501-502.

Carbone E, Lux HD (1987) Kinetics and selectivity of a low-voltageactivated calcium current in chick and rat sensory neurones. J Physiol (Lond) 386:547-570.

Eccles JC, Ito M, Szentagothai J (1967) The cerebellum as a neuronal machine. Berlin: Springer.

Fedulova SA, Kostyuk PG, Veselovsky NS (1985) Two types of calcium channels in the somatic membrane of new-born rat dorsal root ganglion neurones. J Physiol (Lond) 359:431-446.

Forscher P, Oxford GS (1985) Modulation of calcium channels by norepinephrine in internally dialyzed avian sensory neurons. J Gen Physiol 85:743-763.

Fox AP, Nowycky MC, Tsien RW (1987a) Kinetic and pharmacological propertics distinguishing three types of calcium currents in chick sensory neurones. J Physiol (Lond) 394:149-172.

Fox AP, Nowycky MC, Tsien RW (1987b) Single-channel recordings of three types of calcium channels in chick sensory neurones. J Physiol (Lond) 394:173-200. 
Fficl DI), Bean BP (1988) Two ATP-activated conductances in bullfrog atrial cells. J (ien Physiol 91:1--27.

Furshpan E, Potter DD (1989) Seizure-like activity and cellular damage in rat hippocampal neurons in cell culture. Neuron 3:199-207.

Gray R, Johnston I) (1987) Noradrenaline and $\beta$-adrenoceptor agonists increase activity of voltage-dependent calcium channels in hippocampal neurons. Nature 327:620-622.

Hamill OP. Marty A, Neher E, Sakmann B, Sigworth FJ (1981) Improved patch-clamp techniques for high-resolution current recording from cells and cell-free membrane patches. Pfluegers Arch 391:85100

Hirano T. Hagiwatas $S$ (1989) Kinctics and distribution of voltagegated $\mathrm{Ca} . \mathrm{Na}$ and $\mathrm{K}$ channels on the somata of rat cerebellar Purkinje cells. Pfluegers Arch 413:463-469.

Hirning LD, Fox AP. Mc(leskey EW, Olivera BM, Thayer SA. Miller RJ, Tsien RW (1988) Dominant role of $\mathrm{N}$-type $\mathrm{Ca}^{2+}$ channels in cvoked release of norepinephrine from sympathetic neurons. Science 239:57-6) 1

Hockberger PE, 'lseng H-Y. Connor JA (1989) Fura-2 measurements of cultured rat Purkinge neurons show dendritic localization of $\mathrm{Ca}^{2}$ intlux. J Neurosei 9:2272-2284.

Hounsgaard I. Midtgaard J (1988) Intrinsic determinants of firing pattern in Purkinje colis of be turtle cerebellum in vitro. J Physiol (1.ond) $402,731-74$ )

Huang LM :1989) Calcium channels in isolated rat dorsal horn neurones incliding lahelled pinothalamic and rigeminothalamic cells. J Physiol (Lond) 441:161-177.

Huetner JE, Baughman RW (1986) Primary culture of identified neurons from the visual cortex of postnatal rats. J Ncurosci 6:3044-3060.

Ikeda SR, Schofield GG, Weight FF (1986) $\mathrm{Na}^{2}$ and $\mathrm{Ca}^{2-}$ currents of acutely isolated adult rat nodose ganglion cells. J Neurophysiol 55: $527-539$

Kasai H. Aosaki T (1988) Divalent cation dependent inactivation of the high-voltage-activated (a-channel current in chick sensory neurons. Pfluegers Arch 441:695-697.

Kasai H. Aosaki T. Fukuda J (1987) Presynaptic Ca-antagonist $\omega$-conotoxin irreversibly blocks $\mathrm{N}$-type $\mathrm{Ca}$-channels in chick sensory neurons. Neurose1 Res 4:228-235.

Kongsamul S, Lipscombe D, Tsien RW (1989) The N-type Ca channel in frog sympathetic neurons and its role in alpha-adrenergic modulation of transmitter release. Ann NY Acad Sci 560:312-333.

Kostyuk PG, Veselovsky NS, Fedulova SA (1981) Ionic currents in the somatie membrane of rat dorsal root ganglion neurons-II. Calcium currents. Neuroscience 6:2431-2437.

Kostyuk P(i. Shuba Ya M. Savchenko AN (1988) Three types of alcium channels in the membrane of mouse sensory neurons. Pfluegers Arch 411:661-669.
Llinas R, Sugimori M (1980a) Electrophysiological properties of in vitro Purkinje cell soma1a in mammalian cerebellar slices. J Physiol (Lond) 305:171-195.

Llinas R, Sugimori M (1980b) Electrophysiological propertics of in vitro Purkinje cell dendrites in mammalian cerebellar slices. J Physiol (Lond) 305:197-213.

Llinas R, Sugimori M, Cherksey B (1989a) Voltage-dependent calcium conductances in mammalian neurons. Ann NY Acad Sci 560:103111.

Llinas R. Sugimori M. Lin J-W. Cherksey B (1989b) Blocking and isolation of a calcium channel from neurons in mammals and cephalopods utilizing a toxin fraction (FTX) from funnel-weh spider poison. Proc Natl Acad Sci USA 86:1689-1693.

McCleskey EW, Fox AP, Feldman DH, Cruz LJ, Olivera BM, Tsien RW, Yoshikami D (1987) w-Conotoxin: direct and persistent blockade of specific types of calcium channels in neurones but not muscle. Proc Natl Acad Sci USA 84:4327-4331.

Nowycky MC, Fox AP, Isien RW (1985a) Long-opening mode of gating of neuronal calcium channels and its promotion by the dihydropyridine calcium agonist Bay K8644. Proc Natl Acad Sci USA $82: 2178-2182$.

Nowycky MC, Fox AP, Tsien RW (1985b) Three types of neuronal calcium channel with different calcium agonist sensitivity. Nature 316:440-443.

Olivera BM, McIntosh JM, Cru/ LJ. Luque FA, Gray WR (1984) Purification and sequence of a presynaptic peptide ioxin from Conus geographus venom. Biochemistry 23:5087-5090.

Plummer MR, Logothetis DE. Hess P (1989) Elementary properties and pharmacological sensitivities of calcium channels in mammalian peripheral neurons. Neuron 2:1453-1463.

Ross WN, Werman R (1987) Mapping calcium transients in the dendrites of Purkinje cells from the guinea-pig cerebellum in vitro. $\mathrm{J}$ Physiol (Lond) 389:319-336.

Sah DWY (1990) Neurotransmitter modulation of calcium current in rat spinal cord neurons. I Neurosci 10:136-141.

Swandulla D, Armstrong (M (1988) Fast deactivating calcium channels in chick sensory neurons. J Gen Physiol 92:197-218.

Tank DW, Sugimori M, Connor JA, Llinas R (1988) Spatially resolved calcium dynamics of mammalian Purkinje cells in cerebellar slice. Science 242:773-777.

Yaari Y, Hamon B. Lux HD (1987) Development of two types of calcium channels in cultured mammalian hippocampal neurons. Science 235:680-682.

Yellen $G$ (1982) Single $\mathrm{C}^{2}$-activated non-selective channeis in neuroblastoma. Nature 296:357-359. 